\title{
In vivo effect of essential oil of Mentha $x$ villosa and its active compound against Schistosoma mansoni (Sambon, 1907)
}

\author{
T. J. Matos-Rocha, ${ }^{a, b *}$ (D) M. G. S. Cavalcanti ${ }^{a, b, c}$ (D), D. L. Veras ${ }^{a}$, A. F. Santos ${ }^{e}$,

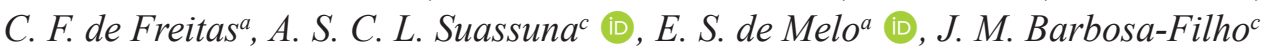 \\ L. C. Alves ${ }^{a, b, d}$ (D) and F. A. Brayner dos Santos ${ }^{a, b}$

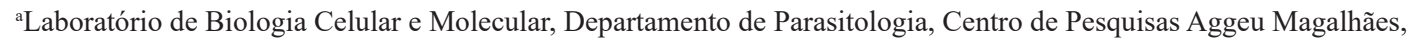 \\ Fundação Oswaldo Cruz, CEP 50670-420, Recife, PE, Brasil \\ 'Laboratório de Imunopatologia Keizo Asami, Universidade Federal de Pernambuco - UFPE, \\ CEP 50670-901, Recife, PE, Brasil \\ 'Universidade Federal da Paraíba - UFPB, CEP 58051-900, João Pessoa, PA, Brasil \\ 'Instituto de Ciências Biológicas, Universidade de Pernambuco - UPE, CEP 50100-130, Santo Amaro, PE, Brasil \\ 'Programa de Pós-graduação em Análise de Sistemas Ambientais - PPGASA, Centro Universitário CESMAC, CEP 57051- \\ 530, Maceió, AL, Brasil \\ *e-mail: thy_rocha@hotmail.com
}

Received: November 17, 2018 - Accepted: March 12, 2019 - Distributed: August 31, 2020

\begin{abstract}
Schistosomiasis treatment is dependent on a single drug, praziquantel (PZQ). The development of resistance of PZQ has drawn the attention of many researchers to alternative drugs. One viable and promising treatment is the study of medicinal plants as a new approach to the experimental treatment for Schistosomiasis. The present work aimed to evaluate in vivo antischistosomal activity of effect of Mentha x villosa Oil Essential (Mv-EO) and rotundifolone (ROT) against Schistosoma mansoni. Thirty-day-old female Swiss webster mice (Mus musculus) weighing 50 grams were used. Mice were infected with 80 cercariae of $S$. mansoni (BH strain) and orally administered Mv-EO (50, $100 \mathrm{and} 200 \mathrm{mg} / \mathrm{Kg}$ ) and $\operatorname{ROT}(35.9,70.9$ and $141.9 \mathrm{mg} / \mathrm{Kg})$ at 45 -days post infection for 5 consecutive days. All mice were euthanized 60 days after infection. Praziquantel was the positive control in the experiment. Doses of $200 \mathrm{mg} / \mathrm{kg}$ (Mv-EO) and ROT $(141.9 \mathrm{mg} / \mathrm{Kg})$ resulted in a significant reduction in fluke burden $(72.44 \%$ and $74.48 \%$, respectively). There was also marked reduction in liver, intestinal and faecal and changed oogram pattern, compared to infected untreated mice. Considering the results obtained, further biological studies are required in order to elucidate the mechanism of schistosomicidal action on against adult S. mansoni.
\end{abstract}

Keywords: Mentha x villosa, óleo essencial, rotundifolona.

\section{Efeito in vivo do óleo essencial de Mentha $x$ villosa e seu composto ativo sobre Schistosoma mansoni (Sambon, 1907)}

\begin{abstract}
Resumo
O tratamento da esquistossomose é dependente de uma única droga, praziquantel (PZQ). O desenvolvimento da resistência de PZQ tem atraído atenção de muitos pesquisadores por medicamentos alternativos. Um tratamento viável e promissor é o estudo das plantas medicinais como uma nova abordagem para o tratamento experimental para esquistossomose. O presente trabalho objetivou avaliar a atividade esquistossomicida in vivo óleo essencial de Mentha $x$ villosa (OE-Mv) e rotundifolona (ROT) contra Schistosoma mansoni. Foram utilizados camundongos Swiss webster (Mus musculus) fêmea de trinta dias de idade pesando 50 gramas. Os camundongos foram infectados com 80 cercárias de $S$. mansoni (cepa BH) e administrado por via oral OE-Mv $(50,100$ e $200 \mathrm{mg} / \mathrm{Kg})$ e ROT $(35,9,70,9$ e $141,9 \mathrm{mg} / \mathrm{Kg})$ apos 45 dias de infecção durante 5 dias consecutivos. Todos os animais foram eutanasiados 60 dias após a infecção. Praziquantel foi o controle positivo no experimento. O tratamento dos camundongos infectados com doses de $200 \mathrm{mg} / \mathrm{kg}$ (OE-Mv) e rotundifolona $(141,9 \mathrm{mg} / \mathrm{Kg})$ resultaram em redução significativa dos vermes $(72.44 \%$ e $74.48 \%$, respectivamente). Foi observado também redução no fígado, intestino e fecal e alteração no padrão do oograma, em comparação aos camundongos infectados e não tratados. Considerando os resultados obtidos, mais estudos biológicos são necessários a fim de elucidar o mecanismo de ação esquistossomicida contra adultos de S. mansoni.
\end{abstract}

Palavras-chave: Mentha x villosa, essencial oil, rotundifolone. 


\section{Introduction}

Schistosomiasis is already a serious public health problem, caused by trematode flatworms of the genus Schistosoma, is one of the most significant, neglected tropical diseases in the world (Gryseels et al., 2006).

Some published studies have reported that widespread use of praziquantel (PZQ) has favored the emergence of isolates of $S$. mansoni refractory to treatment with this medicine drug (Jiwajinda et al., 2002). The considerable concern about the development of PZQ resistance has motivated the scientific community to develop novel and inexpensive drugs against schistosomiasis (Seif el-Din et al., 2014).

The trend of using natural plant extracts as new and safe is promising and constitutes the basis for the development of lead chemicals for therapeutics (Manneck et al., 2009).

The literature showing that artemisinin and its derivatives presented anti-schistosomal potential and were approved as schistosomiasis prevention drugs by the Chinese Ministry of Health. They are active against $S$. japonicum, $S$. mansoni and $S$. haematobium, mainly targeting the immature, pre-adult stage, the schistosomulum (Abdel-Hameed et al., 2008; Botros et al., 2004).

Mentha $x$ villosa (Hudson) such as M. crispa usually reported in the literature belongs to the family Lamiaceae and is known popularly as hortelã-da-folha-miúda, hortelã-rasteira e hortelã-de-panela (Lorenzi and Matos, 2002).

Some studies have been conducted to evaluate therapeutic activities of to the Essential Oil of M. $x$ villosa (Mv-EO) thus adding information about this plant and its major compounds. In the present study, both Mv-EO as and rotundifolone (ROT), its major constituents, is being evaluated for different biological activities such as cardiovascular (Lahlou et al., 2002), hypotensive and bradycardic (Guedes et al., 2004a, b), antimicrobial (Arruda et al., 2006) and antinociceptive (Sousa et al., 2009) for Mv-EO.

Regarding ROT some effects reported in the literature, analgesic (Almeida et al., 1996), relaxant (Sousa et al., 2007), hypotensive and bradycardic (Guedes et al., 2002), antinociceptive (Sousa et al., 2007, 2009), antimicrobial (Arruda et al., 2006) and spasmolytic (Sousa et al., 2008). Studies have also demonstrated a possible mechanism of action involved in the relaxing effect exhibited by ROT (Silva et al., 2011).

Considerable efforts are ongoing in the development of novel drugs for the prevention and treatment of schistosomiasis. Recent studies by our research group have demonstrated in vitro schistosomicidal activity of Mv-EO and ROT, its major constituent (Matos-Rocha et al., 2013). These results led us to continue the study of the in vivo activity of Mv-EO and ROT on schistosomes. The present study aimed to evaluate in vivo effect of $\mathrm{Mv}-\mathrm{EO}$ and its active compound, ROT, against $S$. mansoni infection in mice.

\section{Material and Methods}

\subsection{Ethical standards}

All experiments involving the use of experimental animals were performed in accordance to the ethical standards of Fundação Oswaldo Cruz (FIOCRUZ) and were approved by the in Animal ethics committee (CEUA-FIOCRUZ/PE, No. 06/2010).

\subsection{Medicinal plant}

Fresh leaves of the species M. $x$ villosa were used. They were gathered from the Medicinal Plants Garden of the Research Institute of Drugs and Medicines (IPeFarM), Federal University of Paraiba (UFPB) between April and June 2011, where they were identified and authenticated in locum by Dr. F. J. Abreu Matos (Laboratory of Natural Products, Federal University of Ceará) and by Dr. Raymond Harley of the Royal Botanic Gardens, Kew, England. A voucher specimen was deposited in the Prisco Bezerra Herbarium of the Federal University of Ceará (No. 14996).

\subsection{Essential oil of M. $x$ villosa}

To extract Mv-EO, $10 \mathrm{~kg}$ of the leaves were steam-distilled for $8 \mathrm{~h}$. The oil obtained $(0.1 \%)$ was dried over anhydrous sodium sulfate in the usual manner and stored at $4^{\circ} \mathrm{C}$. We used a gas chromatograph coupled to a mass spectrometer (GC-MS) (Shimadzu QP-500) under the following analytical conditions: capillary colunn, OV-5 (30 m x $0.25 \mathrm{~mm} \times 0.25 \mathrm{~m}$ ); injector (Ohio Valley Specialty Chemical, Inc.) $240^{\circ}$; detector, $230^{\circ}$; electron impact, $70 \mathrm{eV}$; gas drag, He; flow, $1.0 \mathrm{~mL} / \mathrm{min}$; split, $1 / 20$; program temperature, $60^{\circ} \mathrm{C}-240^{\circ} \mathrm{C}$ at $3^{\circ} \mathrm{C} / \mathrm{min}$; and solution injection volume, $1 \mu \mathrm{L}(1 \mu \mathrm{L}$ of $\mathrm{Mv}$-EO per $1 \mathrm{~mL}$ of ethyl acetate). The compounds were identified by comparing their mass spectra using the GC-MS database system (Nist $62 \mathrm{lib}$.) and the Kovats retention index (Matos-Rocha et al., 2013).

\subsection{Obtaining of rotundifolone}

The essential oil of Mentha $x$ villosa was subjected to thin-layer chromatography (Si-gel PF254, 40 × $20 \mathrm{~cm}$ plates; Merck, Darmstadt, Germany). The plates were developed three times with n-hexane as solvent. Two well-separated bands were visible under a UV lamp. The bands were cut and extracted in the usual way using $\mathrm{CH}_{2} \mathrm{Cl}_{2}$ and ROT was obtained from the slower moving band with $99.9 \%$ of purity determined by high-performance liquid chromatograph.

\subsection{Obtaining of praziquantel}

Praziquantel tablets were commercially available through Sigma-Aldrich (Sigma chemical, St Louis, MO, USA) with purity of $99.9 \%$. The batch of Mv-EO, rot and PZQ that was been tested and used previously in our laboratory, was used in the present study (Matos-Rocha et al., 2013).

\subsection{Experimental animals}

Female Swiss webster mice (30-day old, weight $\sim 50$ grams) were obtained from CPqAM-FIOCRUZ/PE. Animals were maintained under environmentally controlled conditions at $23 \pm 2{ }^{\circ} \mathrm{C}$ with $12 / 12 \mathrm{~h}$ light/dark cycle, and fed on standard diet and normal drinking water ad libitum during the duration of the experiment. Infection of 72 mice with cercarie of $S$. mansoni was carried out using a tail 
immersion technique ( $80 \pm$ cercarie/mice). After 45 days post exposure to cercarie, the faecal samples of mice were examined for the presence of $S$. mansoni eggs. The infected mice were then separated and used in the experiments.

\subsection{Maintenance of parasite life-cycle}

Eggs of $S$. mansoni were collected from excrements originating from individuals native of the city of Belo Horizonte, Minas Gerais, Brazil, after reading and signing the terms of agreement. Parasitological analyses were done through the method of Kato-Katz. The Biomphalaria glabrata snails were placed individually in wells of culture plates containing $3 \mathrm{~mL}$ of distilled water, where were added eight to ten miracidia of $S$. mansoni per well. A total of 68 snails were infected, for a period of $2 \mathrm{~h}$, under heat and intense light.

After 30 days of infection, the snails were displayed to the heat and the intense light for $2 \mathrm{~h}$, for elimination of the cercariae that were used for the female mice (Mus musculus) infection. The evolutive cycle of the parasite was kept in the schistosomiasis Laboratory of the Department of Parasitology, Oswaldo Cruz Institute, Pernambuco (FIOCRUZ-PE).

Mice with 30-day old, weighing $\sim 50 \mathrm{~g}$ were housed in cages $(30 \times 20 \times 13 \mathrm{~cm})$ containing sterile wood shaving bed. Standard diet (Labina ${ }^{\circledR}$, Ralston Purina Ltda, São Paulo, Brazil) and water were available ad libitum. Room temperature was kept at $22 \pm 2{ }^{\circ} \mathrm{C}$ and $12: 12 \mathrm{~h}$ light/dark cycle (Pereira et al., 2013).

\subsection{Protocol of treatment}

Mice were randomized into eight groups with nine mice each: Group I, received $50 \mathrm{mg} / \mathrm{Kg}$, Group II, received $100 \mathrm{mg} / \mathrm{Kg}$ and Group III, received $200 \mathrm{mg} / \mathrm{Kg}$ of Mv-EO; Group IV, received $35.9 \mathrm{mg} / \mathrm{Kg}$, Group V, received $70.9 \mathrm{mg} / \mathrm{Kg}$ and Group VI, received $141.9 \mathrm{mg} / \mathrm{Kg}$ of ROT; Group VII, received $200 \mathrm{mg} / \mathrm{Kg}$ of PZQ and Group VIII, received suspension in $7 \%$ tween- 80 and $3 \%$ ethanol. For all treatments, Mv-EO and ROT were administered daily for five consecutive days orally (gavage) using appropriate tube containing a volume of $400 \mu \mathrm{l}$ per mice. Sixty days after treatment with the compounds, the animals were anesthetized with an intraperitoneal injection of ketamine hydrochloride $(115 \mathrm{mg} / \mathrm{Kg})$ associated with xylazine hydrochloride (10 mg/Kg) (Pereira et al., 2013). The recovery of $S$. mansoni worms from the hepatic portal system and mesenteric veins of sacrificed mice was done by the perfusion technique described by Smithers and Terry (Duvall and Dewitt, 1967).

\subsection{Evaluation of the efficacy of treatment}

The evaluation of the efficacy of the Mv-EO and ROT was determined by observing reduction in the percentage of parasitic load in each group treated using the following equation: reduction of fluke $(\%)=\mathrm{n}^{\mathrm{o}}$ of fluke in the control group $-\mathrm{n}^{\mathrm{o}}$ of fluke in the treatment group $\times 100 / \mathrm{n}^{\circ}$ of fluke in the control group.

\subsection{Percentage egg developmental stages}

Three fragments of the distal portion of the intestine were washed in normal saline solution and slightly dried on absorbent paper. Subsequently, each intestinal fragment was squeezed between the slide and the cover slip and analyzed in a microscope to quantify the eggs. For each fragment 100 eggs were counted and classified according to their developmental stage. The eggs were classified as immature, viable eggs (from the 1 st to the 4th stage); mature, viable eggs; and non-viable eggs (calcified, with retracted miracidium, semitransparent) (Fallon et al., 1995).

\subsection{Counting the eggs in the liver and intestine}

Three fragments of the liver and the intestine of each mouse subjected to euthanasia were taken after perfusion and digested in $4 \%$ potassium hydroxide $(\mathrm{KOH})$ (Botros et al., 2004). The recovered eggs found were quantified with the aid of a cell-counting "Sedgewick Rafter" camera (Graticules Limited: model S50, Tonbridge-England) (Pellegrino and Faria, 1965).

\subsection{Counting the eggs in the faecal}

The mice were tested for the elimination of eggs in the faecal through HelmTest Kit which is based on an adaptation of the Kato-Katz (Fashuyi, 1981), available at Biomanguinhos Laboratory Fiocruz/PE. The faecal were subjected to sieving filter provided by the kit and rode up a blade, with certain amount of stool through the fill hole with known diameter (provided by the kit). The preparations were covered with cover slip impregnted with malachite green cellophane paper, aiming at the conservation of faecal and whitening $S$. mansoni eggs. We carried out the reading of the blades and counting of eggs and calculated the number of eggs per gram of faecal using the following formula: Sample number of eggs $/$ gram of feces $=$ number of eggs found on the blade $24 \mathrm{x}$ factor (standardized by kit HelmTest - BioManguinhos).

\subsection{Statistical analysis}

Data were expressed as the mean \pm SD. Statistical analysis was performed using the Tukey test. Differences were considered to be significant when $p<0.001$ for all cases. The software used was GraphPad Prism 5.0.

\section{Results}

\subsection{Worm burden}

The Table 1, the mean numbers of $S$. mansoni recovered after treatment with $\mathrm{Mv}-\mathrm{EO}$ and ROT are presented in Table 1. Reduction rate was $74.48 \%$ and $72.44 \%$ in infected

Table 1. Fluke recovery of $S$. webster mice infected with S. mansoni, treated or nontreated with Mv-EO and ROT.

\begin{tabular}{cc}
\hline Group & Efficacy (\%) \\
\hline I & 8.16 \\
II & 53.06 \\
III & 72.44 \\
V & 13.26 \\
IV & 59.18 \\
VI & 74.48 \\
VII & 95.91 \\
VIII & - \\
\hline
\end{tabular}

Group I: $\mathrm{Mv}-\mathrm{EO} / 50 \mathrm{mg} / \mathrm{Kg}$; group II: $\mathrm{Mv}-\mathrm{EO} / 100 \mathrm{mg} / \mathrm{Kg}$; group III: Mv-EO/200 mg/Kg; group IV: ROT/35.9 mg/Kg; group V: ROT/70.9 mg/Kg; group VI: ROT/141.9 mg/Kg; group VII: $\mathrm{PZQ} / 200 \mathrm{mg} / \mathrm{Kg}$ and group VIII: suspension in $7 \%$ tween- 80 and $3 \%$ ethanol. 
mice treated with $141.9 \mathrm{mg} / \mathrm{Kg}$ and $200 \mathrm{mg} / \mathrm{Kg}$ of ROT and Mv-EO, respectively. PZQ treatment seemed to affect the fluke burden with a reduction of $95.91 \%$ as compared to the infected group.

\subsection{Intestinal, hepatic and faecal eggs count}

Table 2 presents the mean number of $S$. mansoni eggs in the intestinal, hepatic and faecal samples of infected mice treated with Mv-EO and ROT at a dose of $141.9 \mathrm{mg} / \mathrm{Kg}$ (Group III) and $200 \mathrm{mg} / \mathrm{Kg}$ (Group VI) $(p<0.001)$. ROT affected the viability of both mature and immature eggs as indicated by the increase in the percentage of dead eggs and the decrease in the percentage of live ones.

This reduction of faecal egg count could be related to a possible lethal effect of the PZQ on eggs $(p<0.001)$ (Fashuyi, 1981; El-Shenawy et al., 2000; Nahed et al., 2009). Treatment of infected mice with the drugs tested, not caused a significant reduction in the number of intestinal eggs, hepatic eggs, faecal eggs excreted per gram of faecal. In this study, three microscopic slides were analysed and all analyses were performed by double-blind observers.

Although the activity in vivo have demonstrated a significant change in the number of fluke in the treated groups, changes in oogram related to other stages of the eggs of S. mansoni was observed (Table 3 ).

\section{Discussion}

Plants of the genus Mentha contain substances that have been shown to exhibit therapeutic activity against several schistosomiasis (Matos-Rocha et al., 2013). The promising antischistosomal properties of $\mathrm{Mv}-\mathrm{EO}$ and rot reported in this study could be added to its known potency in traditional folk medicine (Lima et al., 2011). Swiss albino mice were used to evaluate the in vivo action of Mv-EO and ROT on survival of $S$. mansoni fluke.

A study conducted by Oliveira et al. (2017) demonstrated in vivo schistosomicidal activity evaluation of crude hexanic (HE) and ethanolic (EE) extracts obtained from Phyllanthus amarus in mice infected with Schistosoma mansoni (BH strain). Mice were treated orally with a single dose of 100 or $250 \mathrm{mg} / \mathrm{kg}$, on two different infection periods, 30 and 45 days post-infection (dpi). Parameters such as worm recovery, faecal egg count, intestinal tissue egg count and liver histopathology were evaluated. Treatment against young adult (30 dpi) and adult (45 dpi) worms were more effective compared to the control group treated with PZQ. At a concentration of $250 \mathrm{mg} / \mathrm{kg}$ (30 dpi) EE showed a $54.4 \%$ female reduction and a $61.2 \%$ total worm reduction whilst at a concentration of $100 \mathrm{mg} / \mathrm{kg}$ (45 dpi) HE showed a $40.6 \%$ female worm reduction and a $45.3 \%$ total worm reduction.

Table 2. Mean number of S. mansoni eggs in the intestinal, hepatic and faecal of mice treated with Mv-EO and ROT.

\begin{tabular}{lccc}
\hline \multicolumn{1}{c}{ Mice } & Intestinal egg count & Hepatic egg count & Faecal egg count \\
\hline Group I & $6023 \pm 135.5$ & $6634 \pm 247.1$ & $409.6 \pm 13.2$ \\
Group II & $5415 \pm 159.6$ & $5725 \pm 103.2$ & $361 \pm 12.9$ \\
Group III & $4846 \pm 125.7$ & $5000 \pm 111.3$ & $314.3 \pm 8.4$ \\
Group IV & $5921 \pm 101.0$ & $6300 \pm 207.2$ & $405.4 \pm 17.2$ \\
Group V & $5119 \pm 149.6$ & $5714 \pm 110.2$ & $366.4 \pm 10.6$ \\
Group VI & $4931 \pm 133.1$ & $5014 \pm 93.6$ & $320 \pm 6.1$ \\
Group VII & $1401 \pm 65.23^{*}$ & $1857 \pm 84.1 *$ & $48.29 \pm 8.4^{*}$ \\
Group VIII & $6357 \pm 105.1$ & $6900 \pm 87.2$ & $499.6 \pm 14.1$ \\
\hline
\end{tabular}

Values are expressed as means $\pm \mathrm{SD}$; *Significant different at $p<0.001$ indicate the percentage of reduction compared with infected control group (group VIII); Group I: Mv-EO/50 mg/Kg; group II: Mv-EO/100 mg/Kg; group III: Mv-EO/200 mg/Kg; group IV: ROT/35.9 mg/Kg; group V: ROT/70.9 mg/Kg; group VI: ROT/141.9 mg/Kg; group VII: PZQ/200 mg/Kg and group VIII: suspension in 7\% tween-80 and 3\% ethanol.

Table 3. Efficacy of Mv-EO and ROT on different stages of development of eggs of S. mansoni.

\begin{tabular}{lccc}
\hline \multirow{2}{*}{ Mice } & \multicolumn{3}{c}{ \% egg developmental stages } \\
\cline { 2 - 4 } & Immature & Mature & Dead \\
\hline Group I & $64.54 \pm 9.80$ & $57.34 \pm 8.83$ & $0.52 \pm 2.38$ \\
Group II & $47.29 \pm 19.76$ & $48.74 \pm 7.65$ & $6.85 \pm 2.86$ \\
Group III & $37.83 \pm 16.32$ & $35.08 \pm 8.65$ & $14.52 \pm 6.69$ \\
Group IV & $63.32 \pm 9.58$ & $59.34 \pm 8.89$ & $0.57 \pm 2.72$ \\
Group V & $48.22 \pm 19.33$ & $45.24 \pm 7.47$ & $6.49 \pm 2.54$ \\
Group VI & $38.73 \pm 11.56$ & $37.62 \pm 8.14$ & $15.48 \pm 6.16$ \\
Group VII & $0.72 \pm 2.33^{*}$ & $14.8 \pm 1.86^{*}$ & $88.21 \pm 11.09^{*}$ \\
Group VIII & $66.11 \pm 9.23$ & $41.24 \pm 8.47$ & $0.49 \pm 2.27$ \\
\hline
\end{tabular}

Values are expressed as means $\pm \mathrm{SD}$; *Significant different at $p<0.001$ indicate the percentage of reduction compared with infected control group (group VIII); Group I: Mv-EO/50 mg/Kg; group II: Mv-EO/100 mg/Kg; group III: Mv-EO/200 mg/Kg; group IV: ROT/35.9 mg/Kg; group V: ROT/70.9 mg/Kg; group VI: ROT/141.9 mg/Kg; group VII: PZQ/200 mg/Kg and group VIII: suspension in 7\% tween-80 and 3\% ethanol. 
The effectiveness on total load of the fluke of S. mansoni is considered a modest result, since according to literature date, a compound has a low efficiency when a reduction in the number of fluke is less than $30 \%$ (Botros et al., 2004). All these findings may suggest a possible anti-S. mansoni activity of the present compounds.

A study conducted by Guimarães et al. (2018) demonstrated the efficacy of epiisopilosine (EPIIS) in a murine model of schistosomiasis. A single dose of EPIIS (100 or $400 \mathrm{mg} / \mathrm{kg}$ ) administered orally to mice infected with adult $S$. mansoni resulted in reduced worm burden and egg production. The treatment with the lower dose of EPIIS (100 mg/kg) significantly reduced total worm burden by $60.61 \%(\mathrm{P}<0.001)$, as well as decreasing hepatosplenomegaly and egg excretion. Scanning electron microscopy revealed morphological changes in the worm tegument after treatment. Despite good activity of EPIIS in adult $\mathrm{S}$. mansoni, oral treatment with single dose of EPIIS $100 \mathrm{mg} / \mathrm{kg}$ had only moderate effects in mice infected with juvenile $S$. mansoni.

Jatsa et al. (2009), El-Ansary et al. (2007), Melo et al. (2011) and Seif el-Din et al. (2014) also obtained considerable reductions of egg in the faecal treating $S$. mansoni-infected mice with Clerodendrum umbellatum extract, Curcuma longa oil extract, cramoll 1.4 lectin see extract and Zingiber offinale extract. The reduction of eggs count is probably the consequence of the noticeable decrease of fluke burden. This is possibly due to a positive linear relationship between the egg output and the fluke burden, where the reduction of the number of worms is correlated with the reduction in the eggs count (Nahed et al., 2009).

Unlike the results obtained in our study, El-Shenawy et al. (2000) observed in their study that the extract of Cleome droserifolia affected oogram with a high percentage of dead eggs pattern. In treated mice, high percentage of dead eggs immature and mature on live compared with infected mice may be related to a possible lethal action of C. droserifolia extract eggs. In the study, the authors did not evaluate whether the eggs were viable or not.

A study conducted by Oliveira et al. (2014) demonstred the in vivo efficacy of Baccharis trimera against schistosomula, juvenile and adult worms of Schistosoma mansoni BH strain. In the experiment, mice were treated with DE, AF and PZQ (40 and $200 \mathrm{mg} / \mathrm{kg}$ ) over the period of larval development ( 3 and 30 post-infection; pi), and adult worms (60days post-infection; pi). The in vitro results show that the DE and AF effects are dose-dependents, being the $130 \mu \mathrm{g} / \mathrm{mL}$ the most effective one in a shorter period of incubation. The exposure of the in vitro samples over adult parasites were able to inhibit $100 \%$ of the oviposition infemales. Likewise caused the mortality of the parasites with morphological alterations on the tegument, on the suckers, oral and acetabulum, in both males and females after 6-72h of exposure. Additionally, the in vivo treatments against juvenile and adult infection were more effective compared to the control group untreated. Administrations of AF and DE in day 30pi (juvenile worms) show female worm total burden reductions of $75 \%$ and $68 \%$ respectively.
At the same period of infection reductions of respectively $98 \%$ and $97 \% \mathrm{egg} / \mathrm{g}$ in the faeces were seen.

In this case, mice may be treated orally using single or multiple oral doses at different life-cycle stages (eggs, schistosomula and juvenile worms). In addition, toxicological studies (e.g., acute oral $\mathrm{LD}_{50}$ ) should be examined.

\section{Conclusion}

Considering the results obtained, further biological studies are required in order to elucidate the mechanism of schistosomicidal action on against adult $S$. mansoni.

\section{Acknowledgements}

To Instituto de Pesquisa em Fármacos e Medicamentos (IPeFarM) of Universidade Federal da Paraíba (UFPB), Laboratório de Imunopatologia Keizo Asami (LIKA) of Universidade Federal de Pernambuco (UFPE) and Núcleo de Plataformas Tecnológicas (NPT) of Centro de Pesquisas Aggeu Magalhães (CPqAM)/FIOCRUZ/PE for support for the experiments and to Coordenação de Aperfeiçoamento de Pessoal de Nível Superior (CAPES) for a scholarship.

\section{References}

ABDEL-HAMEED, E.S., EL-NAHAS, H.A. and ABO-SEDERA, A.S., 2008. Antischistosomal and Antimicrobial Activities of Some Egyptian Plant Species. Pharmaceutical Biology, vol. 46, no. 9, pp. 626-633. http://dx.doi.org/10.1080/13880200802179543.

ALMEIDA, R.N., HIRUMA, C.A. and BARBOSA-FILHO, J.M., 1996. Analgesic effect of rotundifolone in rodents. Fitoterapia, vol. 67 , pp. 334-338.

ARRUDA, T.A., ANTUNES, R.M.P., CATÃO, R.M.R., LIMA, E.O., SOUSA, D.P., NUNES, X.P., PEREIRA, M.S.V., BARBOSA-FILHO, J.M. and CUNHA, E.V.L., 2006. Preliminary study of the antimicrobial activity of Mentha x villosa Hudson essential oil, rotundifolone and its analogues. Revista Brasileira de Farmacognosia, vol. 16, no. 3, pp. 307-311. http://dx.doi. org/10.1590/S0102-695X2006000300005.

BOtRos, S., CIOLI, D., BENNETT, J.L., EBEID, F., DAY, T.A., WILLIAM, S. and KATZ, N., 2004. Lack of evidence for an antischistosomal activity of myrrh in experimental animals. The American Journal of Tropical Medicine and Hygiene, vol. 71, no. 2, pp. 206-210. http://dx.doi.org/10.4269/ajtmh.2004.71.206. PMid:15306712.

DUVALL, R.H. and DEWITT, W.B., 1967. An improved perfusion technique for recovering adult schistosomes from laboratory animals. The American Journal of Tropical Medicine and Hygiene, vol. 16, no. 4, pp. 483-486. http://dx.doi.org/10.4269/ ajtmh.1967.16.483. PMid:4952149.

EL-ANSARY, A.K., AHMED, S.A. and ALY, A.S., 2007. Antischistosomal and liver protective effects of Curcuma longa extract in Schistosoma mansoni infected mice. Indian Journal of Experimental Biology, vol. 45, no. 9, pp. 791-801. PMid:17907745.

EL-SHENAWY, N.S., SOLIMAN, M.F. and ABDEL-NABI, I.M., 2000. Does Cleome droserifolia have anti-schistosomiasis mansoni activity? Rev Inst Med Trop, vol. 48, no. 4, pp. 223- 
228. http://dx.doi.org/10.1590/S0036-46652006000400010. PMid:17119681.

FALLON, P.G., DOENHOFF, M.J., CAPRON, A., STURROCK, R.F. and NIANG, M., 1995. Short report: diminished susceptibility to praziquantel in a Senegal isolate of Schistosoma mansoni. The American Journal of Tropical Medicine and Hygiene, vol. 53, no. 1, pp. 61-62. http://dx.doi.org/10.4269/ajtmh.1995.53.61. PMid:7625534.

FASHUYI, A.S., 1981. Diagnosis of gastro-intestinal helminths of dogs in Lagos area using Kato-Katz technique. Bulletin of Animal Health and Production in Africa, vol. 29, no. 4, pp. 333334. PMid:7348586.

GRYSEELS, B., POLMAN, K., CLERINX, J. and KESTENS, L., 2006. Human schistosomiasis. Lancet, vol. 368, no. 9541, pp. 1106-1118. http://dx.doi.org/10.1016/S0140-6736(06)69440-3. PMid:16997665.

GUEDES, D.N., SILVA, D.F., BARBOSA-FILHO, J.M. and MEDEIROS, I.A., 2002. Muscarinic agonist properties involved in the hypotensive and vasorelaxant responses of rotundifolone in rats. Planta Medica, vol. 68, no. 8, pp. 700-704. http://dx.doi. org/10.1055/s-2002-33795. PMid:12221591.

GUEDES, D.N., SILVA, D.F., BARBOSA-FILHO, J.M. and MEDEIROS, I.A., 2004a. Calcium antagonism and the vasorelaxation of the rat aorta induced by rotundifolone. Brazilian Journal of Medical and Biological Research, vol. 37, no. 12, pp. 1881-1887. http://dx.doi.org/10.1590/S0100-879X2004001200014. PMid:15558195.

GUEDES, D.N., SILVA, D.F., BARBOSA-FILHO, J.M. and MEDEIROS, I.A., 2004b. Endothelium-dependent hypotensive and vasorelaxant effects of the essential oil from aerial parts of Mentha x villosa in rats. Phytomedicine, vol. 11, no. 6, pp. 490-497. http://dx.doi.org/10.1016/j.phymed.2004.04.002. PMid:15500259.

GUIMARÃES, M.A., DE OLIVEIRA, R.N., DE ALMEIDA, R.L., MAFUD, A.C., SARKIS, A.L.V., GANASSIN, R., DA SILVA, M.P., ROQUINI, D.B., VERAS, L.M., SAWADA, T.C.H., ROPKE, C.D., MUEHLMANN, L.A., JOANITTI, G.A., KUCKELhaUS, S.A.S., Allegretti, S.M., MASCARENHAS, Y.P., DE MORAES, J. and LEITE, J.R.S.A., 2018. Epiisopilosine alkaloid has activity against Schistosoma mansoni in mice without acute toxicity. PLoS One, vol. 13, no. 5, pp. e0196667. http://dx.doi.org/10.1371/journal.pone.0196667. PMid:29750792.

JATSA, H.B., SOCK, E.T.N., TCHUENTE, L.A.T. and KAMTCHOUING, P., 2009. Evaluation of the in vivo activity of different concentrations of Clerodendrum umbellatum Poir against Schistosoma mansoni infection in mice. African Journal of Traditional, Complementary, and Alternative Medicines, vol. 7, no. 3, pp. 216-221. PMid:20448845.

JIWAJINDA, S., SANTISOPASRI, V., MURAKAMI, A., KAWANAKA, M., KAWANAKA, H., GASQUET, M., EILAS, R., BALANSARD, G. and OHIGASHI, H., 2002. In vitro antitumor promoting and anti-parasitic activities of the quassinoids from Eurycoma longifolia, a medicinal plant in Southeast Asia. Journal of Ethnopharmacology, vol. 82, no. 1, pp. 55-58. http:// dx.doi.org/10.1016/S0378-8741(02)00160-5. PMid:12169407.

LAHLOU, S., MAGALHÃES, P.J.C., CARNEIRO-LEÃO, R.F.L. and LEAL-CARDOSO, J.H., 2002. Involvement of nitric oxide in the mediation of the hypotensive action of the essential oil of Mentha $x$ villosa in normotensive conscious rats. Planta Medica, vol. 68, no. 8, pp. 694-699. http://dx.doi. org/10.1055/s-2002-33797. PMid:12221590.
LIMA, C.M., FREITAS, F.I., MORAIS, L.C., CAVALCANTI, M.G., SILVA, L.F., PADILHA, R.J., BARBOSA, C.G., SANTOS, F.A., ALVES, L.C. and DINIZ, M.D.E.F., 2011. Ultrastructural study on the morphological changes to male worms of Schistosoma mansoni after in vitro exposure to allicin. Revista da Sociedade Brasileira de Medicina Tropical, vol. 29, no. 3, pp. 327-330. http:// dx.doi.org/10.1590/S0037-86822011005000023. PMid:21537796.

LORENZI, H. and MATOS, J.F.A., 2002. Plantas medicinais no Brasil: nativas e exóticas cultivadas. Nova Odessa: Instituto Plantarum.

MANNECK, T., HAGGENMULLER, Y. and KEISER, J., 2009. Morphological effects and tegumental alterations induced by mefloquine on schistosomula and adult flukes of Schistosoma mansoni. Parasitol, vol. 137, no. 1, pp. 85-98. http://dx.doi. org/10.1017/S0031182009990965. PMid:19814844.

MATOS-ROCHA, T., DOS SANTOS CAVALCANTI, M., BARBOSA-FILHO, J., LÚCIO, A., VERAS, D., FEITOSA, A., DE SIQUEIRA JÚNIOR, J., DE ALMEIDA, R., MARQUES, M., ALVES, L. and BRAYNER, F., 2013. In vitro evaluation of schistosomicidal activity of essential oil of Mentha $x$ villosa and some of its chemical constituents in adult worms of Schistosoma mansoni. Planta Medica, vol. 79, no. 14, pp. 1307-1312. http:// dx.doi.org/10.1055/s-0033-1350732. PMid:23945759.

MELO, C.M., DE LIMA, A.L., BELTRÃO, E.I., CAVALCANTI, C.C., DE MELO-JÚNIOR, M.R., MONTENEGRO, S.M., COELHO, L.C., CORREIA, M.T. and CARNEIRO-LEÃO, A.M., 2011. Potential effects of Cramoll 1,4lectin on murine schistosomiasis mansoni. Acta Tropica, vol. 118, no. 2, pp. 152-158. http://dx.doi.org/10.1016/j.actatropica.2011.01.008. PMid:21333623.

NAHED, H.A., HODA, A.T. and YOMNA, I.M., 2009. Effects of garlic on albino mice experimentally infected with Schistosoma mansoni: a parasitological and ultrastructural study. Tropical Biomedicine, vol. 26, no. 1, pp. 40-50. PMid:19696726.

OLIVEIRA, C.N.F., FREZZA, T.F., GARCIA, V.L., FIGUEIRA, G.M., MENDES, T.M.F. and ALLEGRETTI, S.M., 2017. Schistosoma mansoni: in vivo evaluation of Phyllanthus amarus hexanic and ethanolic extracts. Experimental Parasitology, vol. 183, pp. 56-63. http://dx.doi.org/10.1016/j.exppara.2017.10.008. PMid:29074138.

OLIVEIRA, R.N., REHDER, V.L., OLIVEIRA, A.S., JERALDO, V.D.E.L., LINHARES, A.X. and ALLEGRETTI, S.M., 2014. Anthelmintic activity in vitro and in vivo of Baccharis trimera (Less) DC against immature and adult worms of Schistosoma mansoni. Experimental Parasitology, vol. 139, pp. 63-72. http:// dx.doi.org/10.1016/j.exppara.2014.02.010. PMid:24602876.

PELLEGRINO, J. and FARIA, J., 1965. The oogram method for the screening of drugs in schistosomiasis mansoni. The American Journal of Tropical Medicine and Hygiene, vol. 14, no. 3, pp. 363-369. http://dx.doi.org/10.4269/ajtmh.1965.14.363. PMid:14292740.

PEREIRA, A.S.A., CAVALCANTI, N.L., NASCIMENTO, G.A.F., NASCIMENTO-SILVA, J.L.G., PADILHA, R.J.R., VIEGAS, L.F.W., ALVES, L.C., LIMA-FILHO, J.L. and CHAVES, M.E., 2013. Morphological and morphometric study of cercariae and adult worms of Schistosoma mansoni (SLM strain) isolated from infected mice. Parasitology Research, vol. 112, no. 3, pp. 1087-1096. http://dx.doi.org/10.1007/s00436-0123235-9. PMid:23263251.

SEIF EL-DIN, S.H., EL-LAKKANY, N.M., MOHAMED, M.A., HAMED, M.M., STERNER, O. and BOTROS, S.S., 2014. Potential effect of the medicinal plants Calotropisprocera, 
Ficuselastica and Zingiberofficinale against Schistosoma mansoni in mice. Pharmaceutical Biology, vol. 52, no. 2, pp. 144-150. http:// dx.doi.org/10.3109/13880209.2013.818041. PMid:24047470.

SILVA, D.F., ARAÚJO, I.G.A., ALBUQUERQUE, J.G.F., PORTO, D.L., DIAS, K.L.G., CAVALCANTE, K.V.M., VERAS, R.C., NUNES, X.P., BARBOSA-FILHO, J.M., ARAÚJO, D.A., CRUZ, J.S., CORREIA, N.A. and DE MEDEIROS, I.A., 2011. Rotundifolone-induced relaxation is mediated by BK (Ca) channel activation and $\mathrm{Ca}(\mathrm{v})$ channel inactivation. Basic \& Clinical Pharmacology \& Toxicology, vol. 109, no. 6, pp. 465-475. http://dx.doi.org/10.1111/j.1742-7843.2011.00749.x. PMid:21726408.

SOUSA, D.P., JÚNIOR, E.V.M., OLIVEIRA, F.S., ALMEIDA, R.N., NUNES, X.P. and BARBOSA-FILHO, J.M., 2007. Antinociceptive activity of structural analogues of rotundifolone: structure-activity relationship. Z Naturforsch $C$, vol. 62, no. 1-2, pp. 39-42. http://dx.doi.org/10.1515/znc-2007-1-207. PMid:17425103.

SOUSA, D.P., JÚNIOR, G.A.S., ANDRADE, L.N., CALASANS, F.R., NUNES, X.P., BARBOSA-FILHO, J.M. and BATISTA, J.S., 2008. Structure and spasmolytic activity relationships of monoterpene analogues found in many aromatic plants. $Z$ Naturforsch $C$, vol. 63, no. 11-12, pp. 808-812. http://dx.doi. org/10.1515/znc-2008-11-1205. PMid:19227827.

SOUSA, P.J.C., LINARD, C.F.B.M., AZEVEDO-BATISTA, D., OLIVEIRA, A.C., COELHO-DE-SOUZA, N.A. and LEALCARDOSO, J.H., 2009. Antinociceptive effects of the essential oil of Mentha $x$ villosa leaf and its major constituent piperitenone oxide in mice. Brazilian Journal of Medical and Biological Research, vol. 42, no. 7, pp. 655-659. http://dx.doi.org/10.1590/ S0100-879X2009000700010. PMid:19578645. 